\title{
Critical Terrorism Studies Since 11 September 2001: What Has Been Learned? Edited by David Miller, Jessie Blackbourn, Rani Dhanda and Helen Dexter. New York, NT: Routledge, 2014.
}

Mark Roberts

Security Consultant

Follow this and additional works at: https://digitalcommons.usf.edu/jss

pp. 88-89

\section{Recommended Citation}

Roberts, Mark. "Critical Terrorism Studies Since 11 September 2001: What Has Been Learned? Edited by David Miller, Jessie Blackbourn, Rani Dhanda and Helen Dexter. New York, NT: Routledge, 2014.." Journal of Strategic Security 7, no. 1 (2013) : 88-89.

DOI: http://dx.doi.org/10.5038/1944-0472.7.1.9

Available at: https://digitalcommons.usf.edu/jss/vol7/iss1/10

This Book Review is brought to you for free and open access by the Open Access Journals at Digital Commons @ University of South Florida. It has been accepted for inclusion in Journal of Strategic Security by an authorized editor of Digital Commons @ University of South Florida. For more information, please contact digitalcommons@usf.edu. 
Critical Terrorism Studies Since 11 September 2001: What Has Been Learned? Edited by David Miller, Jessie Blackbourn, Rani Dhanda and Helen Dexter. New York, NT: Routledge, 2014.

\section{Abstract}

Critical Terrorism Studies Since 11 September 2001: What Has Been Learned? Edited by David Miller, Jessie Blackbourn, Rani Dhanda and Helen Dexter. New York, NT: Routledge, 2014. ISBN 978-0-415-83852-8. Graphs. Tables. Sources cited. Index. Pp. viii, 144. \$137.75. 
Roberts: Critical Terrorism Studies Since 11 September 2001

\section{Critical Terrorism Studies Since 11 September 2001: What Has Been Learned? Edited by David Miller, Jessie Blackbourn, Rani Dhanda and Helen Dexter. New York, NT: Routledge, 2014. ISBN 978-0-415-83852-8. Graphs. Tables. Sources cited. Index. Pp. viii, 144. \$137.75.}

Over the last decade, much ink has been spilled on questions such as "what have we learned in the wake of 9/11?" Some studies have been of great value; others have been of negligible value. Unfortunately, Critical Terrorism Studies Since 11 September 2001 has more intrinsic value in its paper and binding rather than the content. At $\$ 137.75$, this book is a terrible investment; it is conceptually vapid and insulting to the informed reader. If its intent is to serve as a text for college or graduate students, its result will be a cadre of alumni with no understanding of the topic, yet in firm command of the politically correct dogmas that mold the modern zeitgeist.

Compiled by university professors (three British and one Australian) with no practical expertise in the topic, the tome is a culturally sensitive diatribe that savages terrorism studies written with a military, intelligence, or security taint. The editors claim such works are "biased, often shoddily researched, and ... too closely identified with the power centres of western states" (p. 1). The book from beginning to end discounts studies undertaken at the behest of military, intelligence, or security interests, while elevating academic and theoretical ones as intellectually and morally superior. The authors seem to ignore any existential threat to democratic societies stemming from terrorism.

The authors claim in their opening salvo that the Iraq war was based on false premises that resulted in the abuse of (British) civil liberties (p. 2), and then decry the dearth of "critical terrorism studies" which they define in purely theoretical terms (Marxist, Postmodernist, critical realist, deconstructionist, discursive practitioner, argumentative turn advocates). The authors complain that there ought to be an environment in which "debate is valued and fostered" (p. 3), and then contradict themselves by claiming that "terrorism expertise" is an oxymoron. The last comment is wrapped in the context of the British government calling as terrorism experts members associated with an "orthodoxy" of security specialists with whom the authors disagree.

The authors' main complaint throughout the book is that governments as a whole do not consult academic experts in the study of terrorism and that they need to include experts in peace and conflict studies, anthropology, politics, international relations, sociology, geography, Middle Eastern studies, feminist theory, and gender studies. With the exception of the last two topics (with all due respect) the authors are living in a bubble with no understanding of how military, intelligence, and governmentally sponsored terrorism studies have adapted to changing times and increased our understanding of an ever morphing field of study.

One contributor decries the reliance on accumulated wisdom vice empirical evidence or statistics. While plausible in the prima facie sense, the author discounts myriad studies performed by the RAND Corporation, the National Counterterrorism Center, the U.S. Department of Defense, the Center for Strategic and International Studies, or the Washington Institute for Near East Policy (to name a few). 
Another author's essay undertakes a view of terrorism studies through an anthropological prism, equating anti-terrorism efforts with divination and witchcraft that elevates a "passion for expert ignorance" (p. 51). His diatribe strains credulity in which he states:

“Counterterrorists' 'passion for ignorance' is well documented on the grounds of basic knowledge regarding the languages or the cultures of the peoples they are engaged with, let alone disinterest in their political goals or subjective motivation." (p. 61)

The author does hit a vein of truth when he observes "inability to sort out real threat from a feigned one is in a nutshell the problem with counterterrorism" (Ibid). After this well stated, astute observation, he then asks rhetorically why "should we not demand from a counterterrorist the basic knowledge and skills of current knowledge as we do from others types?" (p. 61). In both cases, he betrays an incredible level of ignorance of the deep levels of expertise resident in the military and intelligence communities as well as his profound bias against such communities - all this from someone who claims an intellectual and moral high ground.

Yet another contributor outlines a definition of terrorism as a process of political communication and questions how terrorism, as a subset of violence, should even be categorized. She ponders the issue of whether or not any violence communicates a message - intentional or otherwise. She states that "how violence is interpreted is beyond the control of those who carry it out" (pp. 129-30). She further posits that there is no difference between terrorism and other forms of violence. She does admit that terrorism is an exceptionally bad form of violence, but seems uncomfortable even making such a definitive statement.

This book's value lies in its role as a warning - do not buy it! It is plagued by blatant antimilitary and anti-intelligence bias. Ideas presented are enveloped in political theory with no practical approaches to examine or better understand the topic. In sum, this is the worst book I've ever read on the topic, and I've read hundreds of books in this field over the years.

\section{Mark Roberts, Security Consultant}

